\title{
Accuracy of the Polymerase Chain Reaction (PCR) test in the diagnosis of acute respiratory syndrome due to coronavirus: a systematic review and meta-analysis
}

\author{
DIdevaldo Floriano ${ }^{1}$ \\ iD Antônio Silvinato ${ }^{1}$ \\ Wanderley M. Bernardo ${ }^{2}$ \\ João C. Reis ${ }^{1}$ \\ Gabriel Soledade \\ Created on: 20 May, 2020 \\ 1. Programa Diretrizes da $A M B$, São Paulo, SP, Brasil \\ 2. Coordenador do Programa Diretrizes da AMB, São Paulo, SP, Brasil \\ E-mail:wmbernardo@usp.br
}

The Guidelines Project, an initiative of the Brazilian Medical Association, aims to combine information from the medical field in order to standardize producers to assist the reasoning and decision-making of doctors.

The information provided through this project must be assessed and criticized by the physician responsible for the conduct that will be adopted, depending on the conditions and the clinical status of each patient.

\section{INTRODUCTION}

The first case of a patient with a diagnosis of respiratory syndrome due to coronavirus (SARS-COV-2), in the current pandemic, was reported in January 2020, when a patient resident of the city of Wuhan, the Hubei province, in China, was admitted to the central hospital in December 2019¹. Patients affected by the coronavirus 2019 (COVID-19) can be asymptomatic, present mild symptoms (cough, sore throat, fever, diarrhea, myalgia, anosmia), moderate symptoms (weakness, myalgia, dyspnea), or severe symptoms with acute respiratory insufficiency, acute respiratory distress syndrome, and acute kidney failure ${ }^{2}$. The mortality rate can reach $0.5 \%{ }^{3}$.

The "novel coronavirus" belongs to the Coronaviridae family, whose genetic material is the ribonucleic acid (RNA) and which is known to cause influenza and enteric syndromes since 2003. It is associated with Severe Acute Respiratory Syndrome (SARS) ${ }^{4}$ in Asia, with mortality rates of $8.7 \%$ (it reached $50 \%$ among people aged over 60 years), and in the Middle East
Meridian East Respiratory Syndrome (MERS) in 2013, with $40 \%$ of mortality ${ }^{5}$.

The etiological diagnosis of SARS-COV-2 he is currently carried out using the Polymerase Chain Reaction (PCR) technique to detect viral RNA in the sample; enzyme-linked immunosorbent assay (ELIZA) to detect the presence of antibodies in serum (rapid tests to detect antibodies or antigens), ${ }^{6}$ and computed tomography ${ }^{7}$. The PCR technique provides better accuracy when carried out between 2 and 5 days after the onset of symptoms, with the collection of material via $\mathrm{oral} /$ nasal swab or sputum ${ }^{8-11}$; serological tests may be collected starting at the seventh day (Figure 1).

The evolution of the PCR technique resulted in a reduction in the time for executing the examination and in quantification. The real-time polymerase chain reaction (RT-PCR) uses primers that target the upE and ORF1a areas of the coronavirus genome ${ }^{12-13}$. During the PCR technique, reverse transcription can monitor the progress of the process as it takes place (in 
FIGURE 1. CORRESPONDENCE BETWEEN THE VIRAL LOAD AND INFECTION BY THE CORONAVIRUS 2 (SARS-COV-2), CLINICAL SYMPTOMS, AND POSITIVE RRT-PCR.

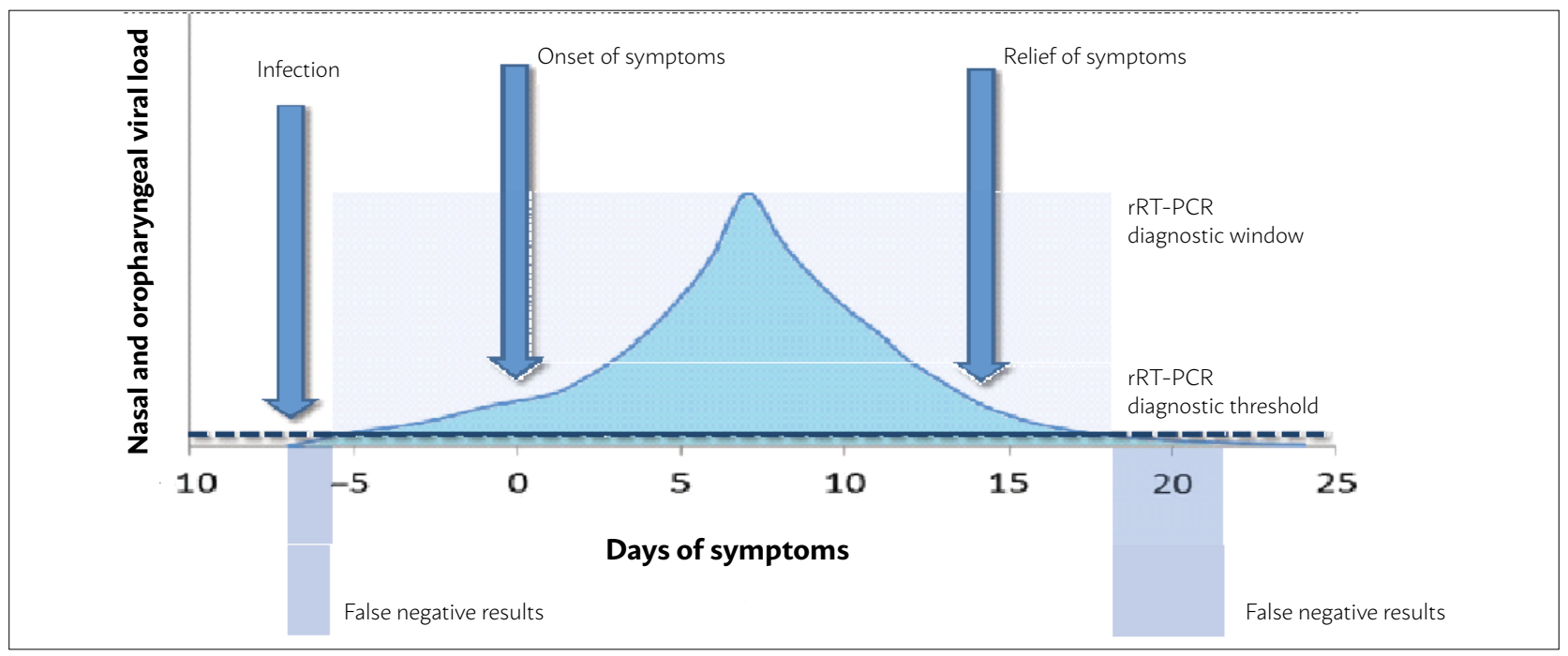

Source: Adapted from Lippi (2020, p 4).

real-time), and the data are collected throughout the examination. The "TaqMan System ${ }^{\circledR}$ " uses a fluorescent probe for quantification and the "SYBR Green I System ${ }^{\circledR}$ uses a dye that binds specifically to DNA and accumulates during cycles for quantification. Currently, there are other enhancements to the PCR technique that aim to decrease costs and facilitate the execution of the technique.

\section{OBJECTIVE}

The objective of this review is to identify the efficacy of the PCR test in the diagnosis of patients with coronavirus.

\section{METHODS}

The clinical question is: What is the efficacy of the PCR test in the coronavirus diagnosis?

Eligibility criteria:

- Patients with a suspicion of coronavirus infection;

- Coronaviruses diagnosis by PCR;

- Collection of nasopharyngeal (NF) and/or oropharyngeal (OF) swab samples;

- Studies on the diagnosis of SARS, MERS, and SARS-COV-2;

- Clinical trials with better evidence and quality;

- No time or language restrictions;

- Full texts available for access, with results on PCR sensitivity and specificity;

- Studies with incomplete data for specificity and sensitivity and viral panel for etiologic diagnosis of respiratory tract infection will be excluded.

The search for evidence will be conducted on the following virtual scientific information databases, using the search strategies:

MEDLINE/PUBMED: ((COVID OR COV OR nCOV OR CORONAVIRUS) AND (PCR OR Polymerase Chain Reaction OR Nucleic Acid Amplification OR Nucleic Acid Amplification Techniques OR Reverse Transcriptase Polymerase Chain Reaction) AND (diagnosis/ broad[filter])), date 04/2020.

CENTRAL COCHRANE: (COVID OR COV OR nCOV OR CORONAVIRUS) AND (PCR OR Polymerase Chain Reaction OR Nucleic Acid Amplification OR Nucleic Acid Amplification Techniques OR Reverse Transcriptase Polymerase Chain Reaction), date 04/2020.

The information obtained from the characteristics of the studies selected were: author's name and year of the study, study design, number of patients, population, type of test, and comparison, described in Table 1.

Data from the results will be collected in absolute numbers provided directly or by information inferred from what is reported in the text. The results from the studies will be placed in a $2 \times 2$ table, where true positive, false positive, true negative, and false negative results will be compiled. The data collection and meta-analysis process will be completed by two independent authors and revised by all authors. Disagreements will be resolved by consensus and discussion between all authors. 


\section{Bias assessment and quality of evidence}

The methodology used to assess the quality of the studies was the Quality Assessment of Diagnostic Accuracy Studies 2 (QUADAS-2) ${ }^{14}$ tool, which was applied by two independent authors. Disagreements were resolved by consulting with a third independent author.

\section{Data Analysis}

The data will be extracted for the primary outcome of accuracy of the test RT-PCR for coronavirus diagnosis. The data collected will be true positive, false positive, true negative, and false negative results, sensitivity, and specificity, which will be analyzed in a $2 \times 2$ Table using the Catmaker Tables ${ }^{15}$ software.

The results of the studies included may be aggregated and meta-analyzed using the Meta-Disc software Version $1.4^{16}$, through which results on the sensitivity, specificity, and positive likelihood ratio, negative likelihood ratio, and SROC curve will be obtained.

\section{RESULTS}

In the search for evidence, we recovered 1260 studies, of which 107 were selected based on their titles, 6 based on the abstract, 28 were excluded, and 22 were evaluated in full. Of the 22 studies, 9 were excluded and $13^{17-29}$ were selected to support this assessment; the grounds for exclusion and list of studies excluded are available in the references, Table 1, and Figure 7, in the Annexes.

The characteristics of the populations included and results extracted are summarized in Tables 2 and 3, in the Annexes.
The thirteen studies included in this review were effectively cross-sectional, with no sample size calculation, conducted in a single institution, including a total of 6295 samples taken through nasal and/or oropharynx swab.

\section{Bias assessment and quality of evidence}

We used the QUADAS-2 ${ }^{14}$ tool to assess the quality of the thirteen studies included in this review (Figure 4). In the selection of patients, we found a low risk of bias in 12 studies (92\%) and low-medium risk in one $(8 \%)$. In the evaluation of the index tests, we found ten studies $(77 \%)$ with low risk of bias, two studies (15\%) with low-moderate risk, and one with moderate risk (8\%). In comparison to the test considered the gold standard (reference), we found twelve studies (92\%) with low risk of bias, and one with moderate risk. Regarding flow and time biases, eleven studies (85\%) had a low risk, and two (15\%) moderate risk.

\section{Meta-analysis}

Thirteen studies ${ }^{17-29}$ presented data possible to be meta-analyzed. The sensitivity (Figure 2) of the PCR technique for coronavirus diagnosis was $86 \%$ (95\% CI $=84$ to $88 \%$ ); $\mathrm{I}^{2}=85 \%$.

The estimate of specificity calculated for the studies (Figure 3) was 96\% (95\% CI = 94 to $97 \%)$; $\mathrm{I}^{2}=0 \%$.

The results for a positive likelihood ratio (Figure 4) was $18.8(95 \% \mathrm{CI}=14.5$ to 24.3$) ; \mathrm{I}^{2}=0 \%$.

The results for a negative likelihood ratio (Figure 5) was $0.13(95 \% \mathrm{CI}=0.1$ to 0.19$) ; \mathrm{I}^{2}=83.6 \%$.

Analyzing the SROC curve (Figure 6), we estimated the value of the area under the curve (AUC) as 0.977 and $\mathrm{Q}=0.93$.

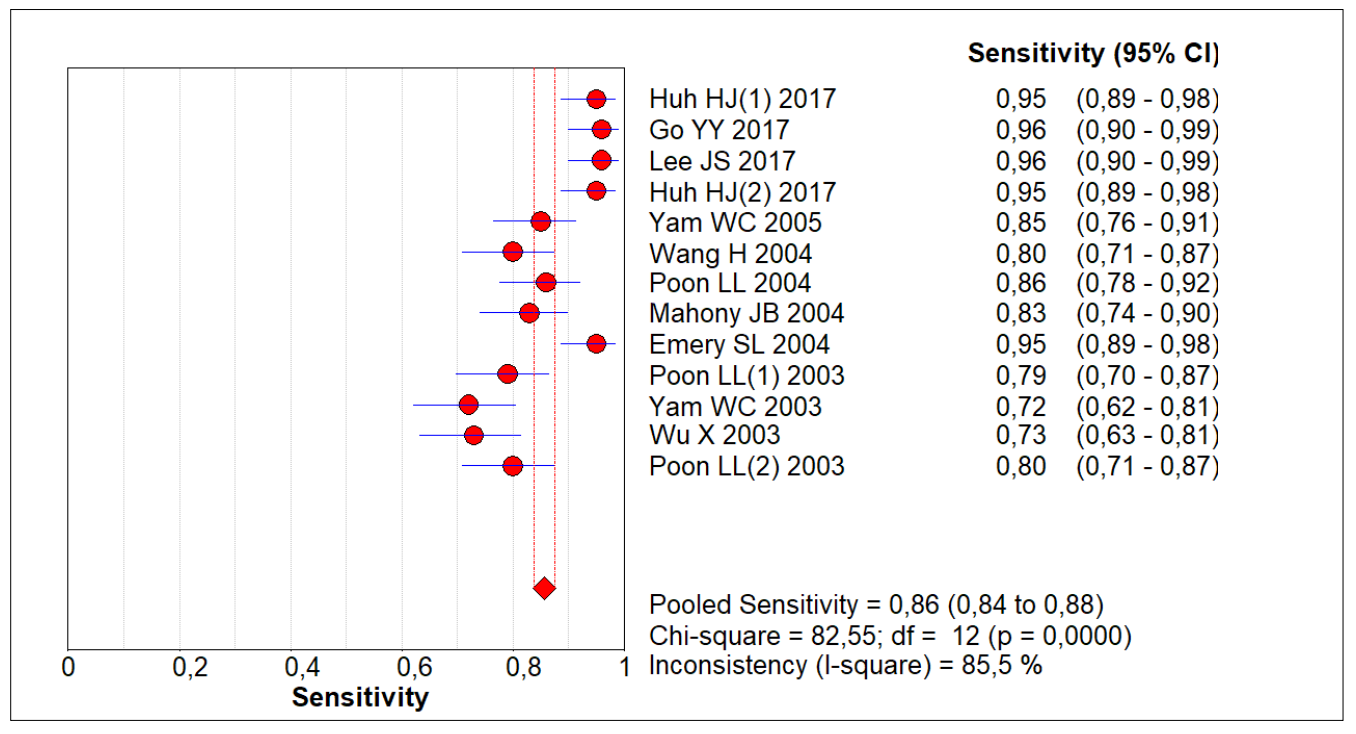

FIGURE 2.

FOREST PLOT OF SENSITIVITY ESTIMATE IN THE CORONAVIRUS DIAGNOSIS BY PCR. 


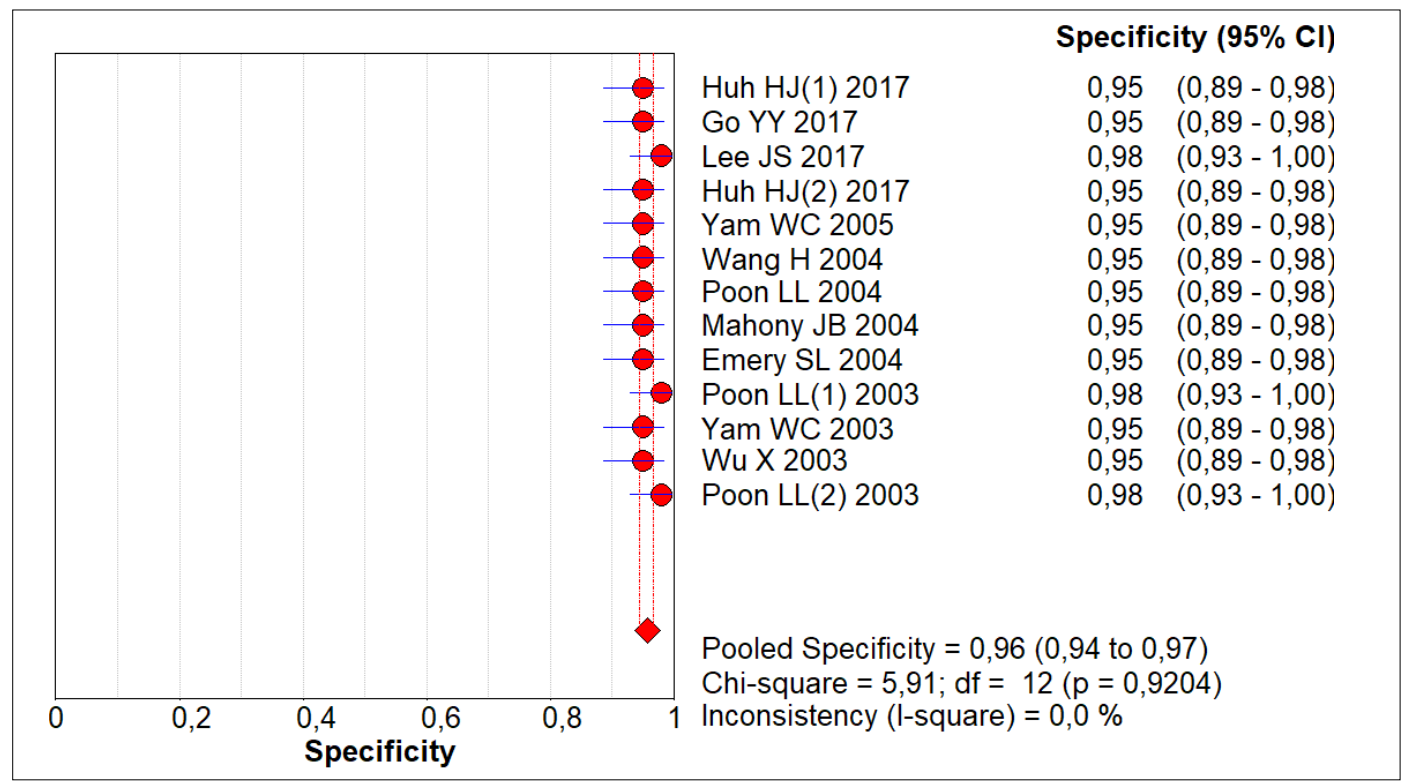

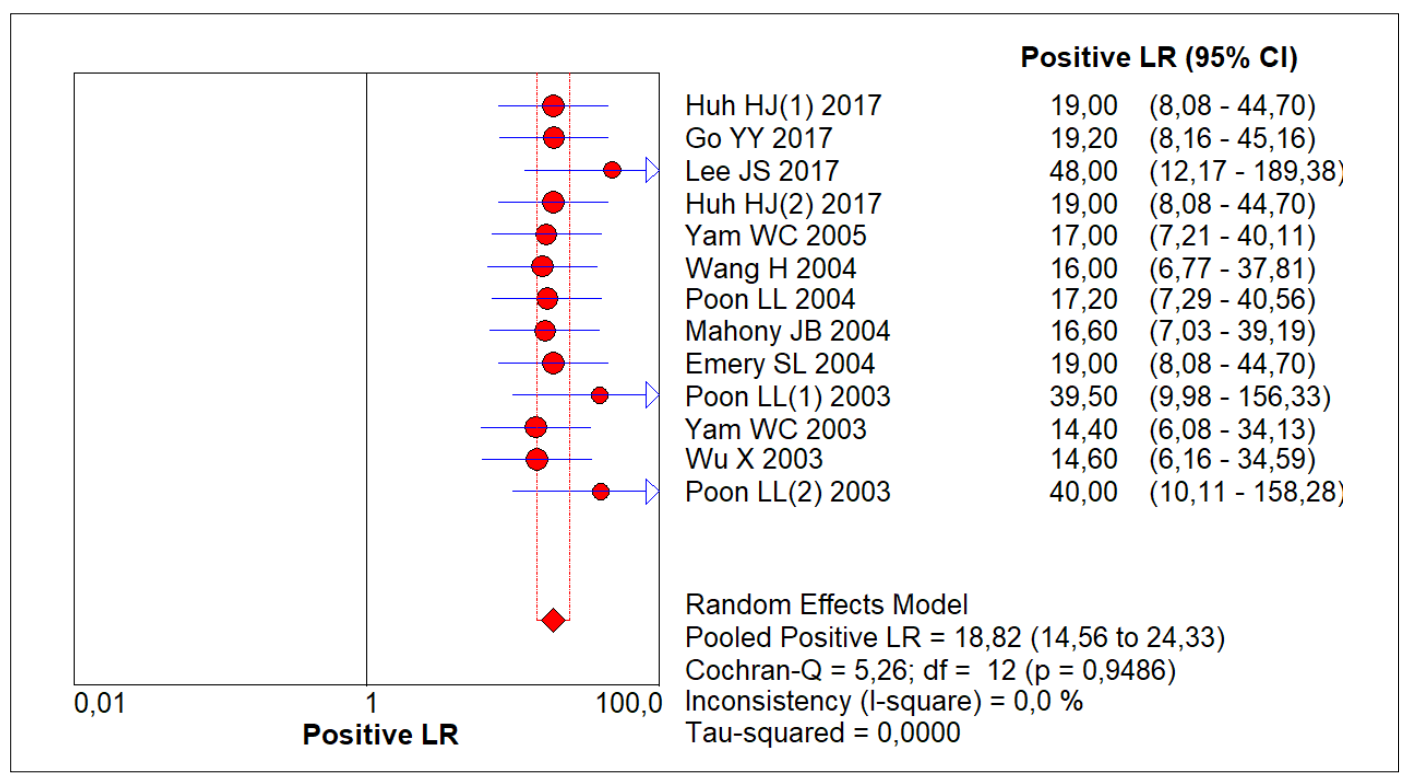

FIGURE 3.

FOREST PLOT OF SPECIFICITY ESTIMATE IN THE CORONAVIRUS DIAGNOSIS BY PCR

FIGURE 4

FOREST PLOT OF THE POSITIVE LIKELIHOOD RATIO ESTIMATE IN THE CORONAVIRUS DIAGNOSIS BY PCR

FIGURE 5.

FOREST PLOT OF THE NEGATIVE LIKELIHOOD RATIO IN THE CORONAVIRUS DIAGNOSIS BY PCR 


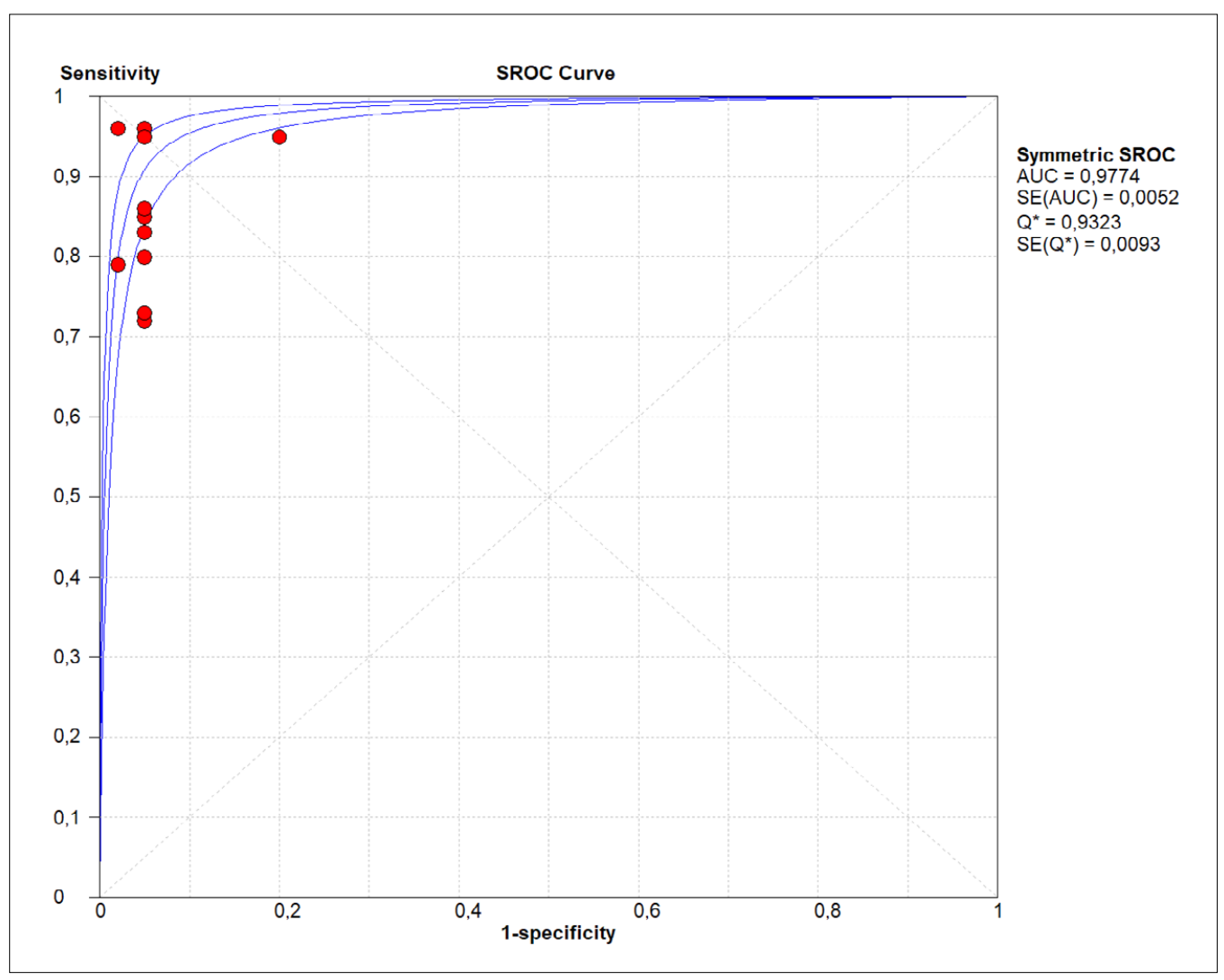

FIGURE 6. SUMMARY RECEIVER OPERATING CHARACTERISTIC CURVE (SROC) IN THE DIAGNOSIS OF CORONAVIRUS BY PCR

\section{DISCUSSION}

Since 2003, there have been cases of respiratory syndromes whose etiology is due to a coronavirus infection, with two previous epidemic outbreaks (SRAS-VOC, and MERS). In November 2019, a new outbreak began, of pandemic proportions, which has spread throughout the world at great speed, causing a large number of deaths and morbidities. At the same speed as the virus propagation, research was carried out for diagnosis and treatment of the pathology.

In this review, we looked for scientific studies of the best quality available to evaluate the accuracy of the PCR test for coronavirus diagnosis.

During our search, we retrieved only cross-sectional observational studies to support the evidence of the review, which provided us moderate quality and a low risk of bias. However, Deeks JJ, et al. ${ }^{30}$ found a high risk of bias and low quality when they evaluated, through a systematic review, the serologic diagnosis test for COVID-19. This result was probably due to the methodological rigor applied in the assessment using the QUADAS-2 tool.

In this review, we searched for studies with suspected or diagnosed respiratory infection by the coronavirus in human patients. The PCR technique was adopted in all studies, with minor variations that do not interfere in their accuracy.
The values obtained through the meta-analysis were: sensitivity (86\%), specificity (96\%), positive likelihood ratio (18.82), a negative likelihood ratio (0.13), and area under the curve (AUC) (0.97).

The accuracy of the PCR test for coronavirus diagnosis can change according to the prevalence of the disease.

We can simulate 3 situations:

- With a prevalence of 50\%, common among health professionals with respiratory symptoms, we found a post-test probability of $96 \%$.

- With a prevalence of $20 \%$, the post-test probability was $84 \%$.

- With a prevalence of $5 \%$, there is a $55 \%$ posttest probability.

As we can observe, even with high sensitivity and specificity of the PCR test for coronavirus diagnosis, we can obtain different results regarding its effectiveness.

We can interpret that when the test is applied in conditions of low prevalence of the disease, it allows a precise diagnosis in $55 \%$ of the cases.

Hypothetically, when carrying out a second consecutive test in the same patient, considering a prevalence of $96 \%$ (post-test probability of the first test with an 
initial prevalence of 50\%), there is a post-test probability of approximately 100\% (diagnostic accuracy).

We should also point out the factors that can influence the results of the examination, thus producing false negative results, such as: technique and place of collection, time of onset of symptoms, storage and transportation of the sample to the location of the examination.

\section{Synthesis of evidence}

The PCR technique for coronavirus diagnosis provides a sensitivity of $86 \%$ and specificity of $96 \%$; however, it should be applied in contexts of a high prevalence of coronavirus infection (not specific of SARS-Cov-2). When there is uncertainty regarding the diagnosis, a second sample collection can be indicated to confirm the diagnosis. Moderate quality of evidence.

\section{ANNEXES}

TABLE 1. STUDIES EXCLUDED AND REASON

\begin{tabular}{l|l|l} 
Study and year & PMID & Reason for exclusion \\
\hline 1. Long C 2020 & 32229322 & Comparison between CT and RT-PCR \\
\hline 2. Yan C 2020 & 32276116 & Comparison between PCR techniques \\
\hline 3. Fang Y 2020 & 32073353 & Comparison between CT and RT-PCR \\
\hline 4. Shirato k 2018 & 29763640 & Comparison between PCR techniques \\
\hline 5. Pas SD 2015 & 26209385 & Absent specificity data \\
\hline 6. Shirato K 2014 & 25103205 & Absent specificity data \\
\hline 7. Cho CH 2014 & 24582583 & Absent specificity data \\
\hline 8. Cho CH 2013 & 23743345 & Absent specificity data \\
\hline 9. Corman VM 2012 & 23041020 & Absent specificity data \\
\hline
\end{tabular}

TABLE 2. DESCRIPTION OF THE CLINICAL CHARACTERISTICS OF THE STUDIES INCLUDED.

\begin{tabular}{|c|c|c|c|c|c|}
\hline Studies & PMID & DESIGN & POPULATION & TEST & COMPARISON \\
\hline $\begin{array}{l}\text { Huh HJ } \\
2017\end{array}$ & 28840986 & $\begin{array}{l}\text { Cross-sec- } \\
\text { tional }\end{array}$ & $\begin{array}{l}100 \text { samples were analyzed ( } 90 \text { sputum, } 10 \\
\text { NF swabs), collected from } 100 \text { different pa- } \\
\text { tients between June and July } 2015.50 \text { samples } \\
\text { were from patients with clinical suspicion of } \\
\text { SARS and } 50 \text { asymptomatic ones. }\end{array}$ & $r R T-P C R$ & $\begin{array}{l}\text { Nested RT-PCR and } \\
\text { sequencing of the RNA } \\
\text { polymerase gene (RdRp) } \\
\text { and } N \text {. }\end{array}$ \\
\hline $\begin{array}{l}\text { Huh HJ } \\
2017\end{array}$ & 27834073 & $\begin{array}{l}\text { Cross-sec- } \\
\text { tional }\end{array}$ & $\begin{array}{l}\text { 5,330 samples of 3,484 patients with suspect- } \\
\text { ed SARS-CoV were analyzed ( } 4291 \text { sputum, } \\
145 \text { AT, } 732 \text { NF, } 35 \text { OF, } 62 \text { NF and OF, and } 65 \\
\text { others). }\end{array}$ & $\begin{array}{l}\text { Real-time RT-PCR upE } \\
\text { and ORF1a }\end{array}$ & $\begin{array}{l}\text { Different locations of } \\
\text { sample collection }\end{array}$ \\
\hline $\begin{array}{l}\text { Go YY } \\
2017\end{array}$ & 28807812 & $\begin{array}{l}\text { Cross-sec- } \\
\text { tional }\end{array}$ & $\begin{array}{l}\text { Total of } 55 \text { samples collected from } 20 \text { patients } \\
\text { positive for MERS, in } 2015 \text {. Sputum collection. } \\
48 \text { samples of control individuals. } \\
\text { Sensitivity analysis of the ORF1a and upE } \\
\text { gene sequence. }\end{array}$ & $R T-q P C R$ & $R T-q P C R$ \\
\hline $\begin{array}{l}\text { Lee JS } \\
2017\end{array}$ & 28566313 & $\begin{array}{l}\text { Cross-sec- } \\
\text { tional }\end{array}$ & $\begin{array}{l}\text { Total of } 55 \text { samples collected from } 20 \text { patients } \\
\text { positive for MERS, in } 2015 \text {. Sputum collection. } \\
48 \text { samples of control individuals. } \\
\text { Sensitivity analysis of the ORF1a and upE } \\
\text { gene sequence. }\end{array}$ & $r R T-P C R$ & $\begin{array}{l}\text { MagNA Pure } 96 \text { RNA } \\
\text { extraction kit }\end{array}$ \\
\hline $\begin{array}{l}\text { Yam WC } \\
2005\end{array}$ & 15797361 & $\begin{array}{l}\text { Cross-sec- } \\
\text { tional }\end{array}$ & $\begin{array}{l}\text { Patients with clinical suspicion of SARS. } 54 \text { NF } \\
\text { samples collected and } 10 \text { OF by swab }\end{array}$ & rRT-PCR & Conventional PCR \\
\hline $\begin{array}{l}\text { Wang H } \\
2004\end{array}$ & 15229153 & $\begin{array}{l}\text { Cross-sec- } \\
\text { tional }\end{array}$ & $\begin{array}{l}44 \text { patients with SARS admitted and diag- } \\
\text { nosed based on the WHO definition were } \\
\text { selected }\end{array}$ & RT-PCR & Serological conversion \\
\hline $\begin{array}{l}\text { Poon LL } \\
2004\end{array}$ & 15135737 & $\begin{array}{l}\text { Cross-sec- } \\
\text { tional }\end{array}$ & $\begin{array}{l}\text { Extraído } 86 \text { amostras de aspirados naso- } \\
\text { faríngeos de pacientes que apresentaram } \\
\text { diagnóstico clínico de SARS, com evidência } \\
\text { sorológica de infecção por SARS-CoV }\end{array}$ & $\begin{array}{l}\text { 1- One step quantitative } \\
\text { RT-PCR (monoplex) }\end{array}$ & Serological conversion \\
\hline
\end{tabular}




\begin{tabular}{|c|c|c|c|c|c|}
\hline Studies & PMID & DESIGN & POPULATION & TEST & COMPARISON \\
\hline $\begin{array}{l}\text { Mahony } \\
\text { JB } 2004\end{array}$ & 15070991 & $\begin{array}{l}\text { Cross-sec- } \\
\text { tional }\end{array}$ & $\begin{array}{l}17 \text { NF/OF samples collected from patients } \\
\text { with probable SARS between March and April } \\
2003 \text {, in Toronto, Canada. }\end{array}$ & $\begin{array}{l}\text { Seven types of reverse } \\
\text { transcription-PCR (RT- } \\
\text { PCR) tests - } 3 \text { conven- } \\
\text { tional and } 4 \text { real-time }\end{array}$ & Culture of virus \\
\hline $\begin{array}{l}\text { Emery } \\
\text { SL } 2004\end{array}$ & 15030703 & $\begin{array}{l}\text { Cross-sec- } \\
\text { tional }\end{array}$ & $\begin{array}{l}\text { Total of } 340 \text { samples by nasal and oral swab, } \\
\text { from } 246 \text { people with confirmed or suspected } \\
\text { infection by SARS-CoV. }\end{array}$ & $\begin{array}{l}\text { TaqMan real-time } \\
\text { RT-PCR }\end{array}$ & Culture of virus \\
\hline $\begin{array}{l}\text { Poon LL } \\
2003\end{array}$ & 12765993 & $\begin{array}{l}\text { Cross-sec- } \\
\text { tional }\end{array}$ & $\begin{array}{l}29 \text { patients selected ( } 29 \text { samples) with SARS } \\
\text { and infections confirmed clinically and sero- } \\
\text { logically, in Hong Kong, between February and } \\
\text { March } 2003 .\end{array}$ & Conventional RT-PCR & $\begin{array}{l}\text { Patients with clinical and } \\
\text { serological diagnosis }\end{array}$ \\
\hline $\begin{array}{l}\text { Yam WC } \\
2003\end{array}$ & 14532176 & $\begin{array}{l}\text { Cross-sec- } \\
\text { tional }\end{array}$ & $\begin{array}{l}124 \text { NF and } 65 \text { OF samples collected from } 163 \\
\text { patients hospitalized, in Hong Kong, between } \\
\text { February and April 2003, with clinical suspi- } \\
\text { cion of SARS, based on the WHO criteria. }\end{array}$ & $\begin{array}{l}\text { RT-PCR - Evaluating } \\
\text { two first-generation } \\
\text { reverse transcription } \\
\text { tests (WHO-HKU and } \\
\text { WHO-Hamburg RT- } \\
\text { PCR assays) }\end{array}$ & Serological conversion \\
\hline $\begin{array}{l}\text { WuX } \\
2003\end{array}$ & 12890368 & $\begin{array}{l}\text { Cross-sec- } \\
\text { tional }\end{array}$ & $\begin{array}{l}97 \text { samples ( } 67 \text { from patients with SARS e } 30 \\
\text { from healthy individuals) }\end{array}$ & RT-PCR & $\begin{array}{l}\text { Healthy vs. diseased } \\
\text { samples }\end{array}$ \\
\hline $\begin{array}{l}\text { Poon LL } \\
2003\end{array}$ & 14522060 & $\begin{array}{l}\text { Cross-sec- } \\
\text { tional }\end{array}$ & $\begin{array}{l}50 \text { patients with a clinical diagnosis of SARS } \\
\text { were included, based on the WHO criteria, } \\
\text { with a subsequent serological confirmation. } \\
50 \text { NF samples collected 1-3 days after symp- } \\
\text { tom onset }\end{array}$ & $\begin{array}{l}\text { Real-time RT-PCR in } \\
\text { serum and nasopharyn- } \\
\text { geal aspirate samples }\end{array}$ & $\begin{array}{l}\text { NF samples from healthy } \\
\text { individuals and patients } \\
\text { who presented other } \\
\text { viruses were considered } \\
\text { negative controls. }\end{array}$ \\
\hline
\end{tabular}

$\mathrm{NF}=$ nasopharyn $x, \mathrm{OF}=$ oropharyn $x, \mathrm{PCR}=$ polymerase chain reaction, $\mathrm{RT}-\mathrm{PCR}=$ real-time $\mathrm{PCR}, \mathrm{WHO}=$ World Health Organization.

TABLE 3. RESULTS EXTRACTED FROM THE STUDIES INCLUDED.

\begin{tabular}{|c|c|c|c|c|}
\hline \multicolumn{5}{|c|}{ RT-PCR results - COVID } \\
\hline Studies & PMID & DESIGN & Sensit. & Specif. \\
\hline $\begin{array}{l}\text { Huh HJ } \\
2017\end{array}$ & 28840986 & Cross-sectional & 0.95 & 0.95 \\
\hline Go YY 2017 & 28807812 & Cross-sectional & 0.96 & 0.95 \\
\hline Lee JS 2017 & 28566313 & Cross-sectional & 0.96 & 0.98 \\
\hline $\begin{array}{l}\text { Huh HJ } \\
2017\end{array}$ & 27834073 & Cross-sectional & 0.95 & 0.95 \\
\hline $\begin{array}{l}\text { Yam WC } \\
2005\end{array}$ & 15797361 & Cross-sectional & 0.85 & 0.95 \\
\hline $\begin{array}{l}\text { Wang H } \\
2004\end{array}$ & 15229153 & Cross-sectional & 0.80 & 0.95 \\
\hline $\begin{array}{l}\text { Poon LL } \\
2004\end{array}$ & 15135737 & Cross-sectional & 0.86 & 0.95 \\
\hline $\begin{array}{l}\text { Mahony JB } \\
2004\end{array}$ & 15070991 & Cross-sectional & 0.83 & 0.94 \\
\hline $\begin{array}{l}\text { Emery SL } \\
2004\end{array}$ & 15030703 & Cross-sectional & 0.95 & 0.95 \\
\hline $\begin{array}{l}\text { Poon LL } \\
2003\end{array}$ & 12765993 & Cross-sectional & 0.79 & 0.98 \\
\hline $\begin{array}{l}\text { Yam WC } \\
2003\end{array}$ & 14532176 & Cross-sectional & 0.72 & 0.95 \\
\hline Wu X 2003 & 12890368 & Cross-sectional & 0.73 & 0.95 \\
\hline $\begin{array}{l}\text { Poon LL } \\
2003\end{array}$ & 14522060 & Cross-sectional & 0.80 & 0.98 \\
\hline
\end{tabular}

FIGURE 7. FLOWCHART - THE SELECTION OF RETRIEVED FROM THE VIRTUAL DATABASES OF SCIENTIFIC INFORMATION IS DETAILED IN THE FLOWCHART BELOW:

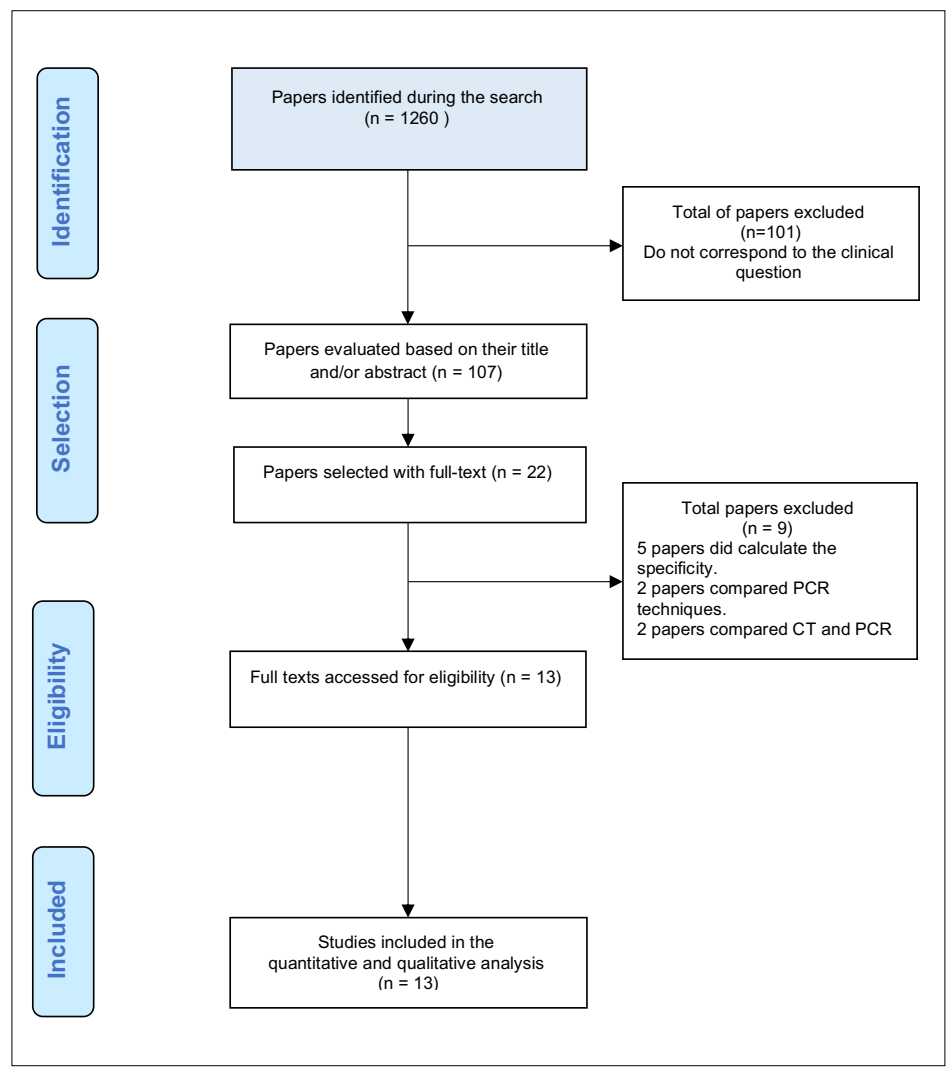




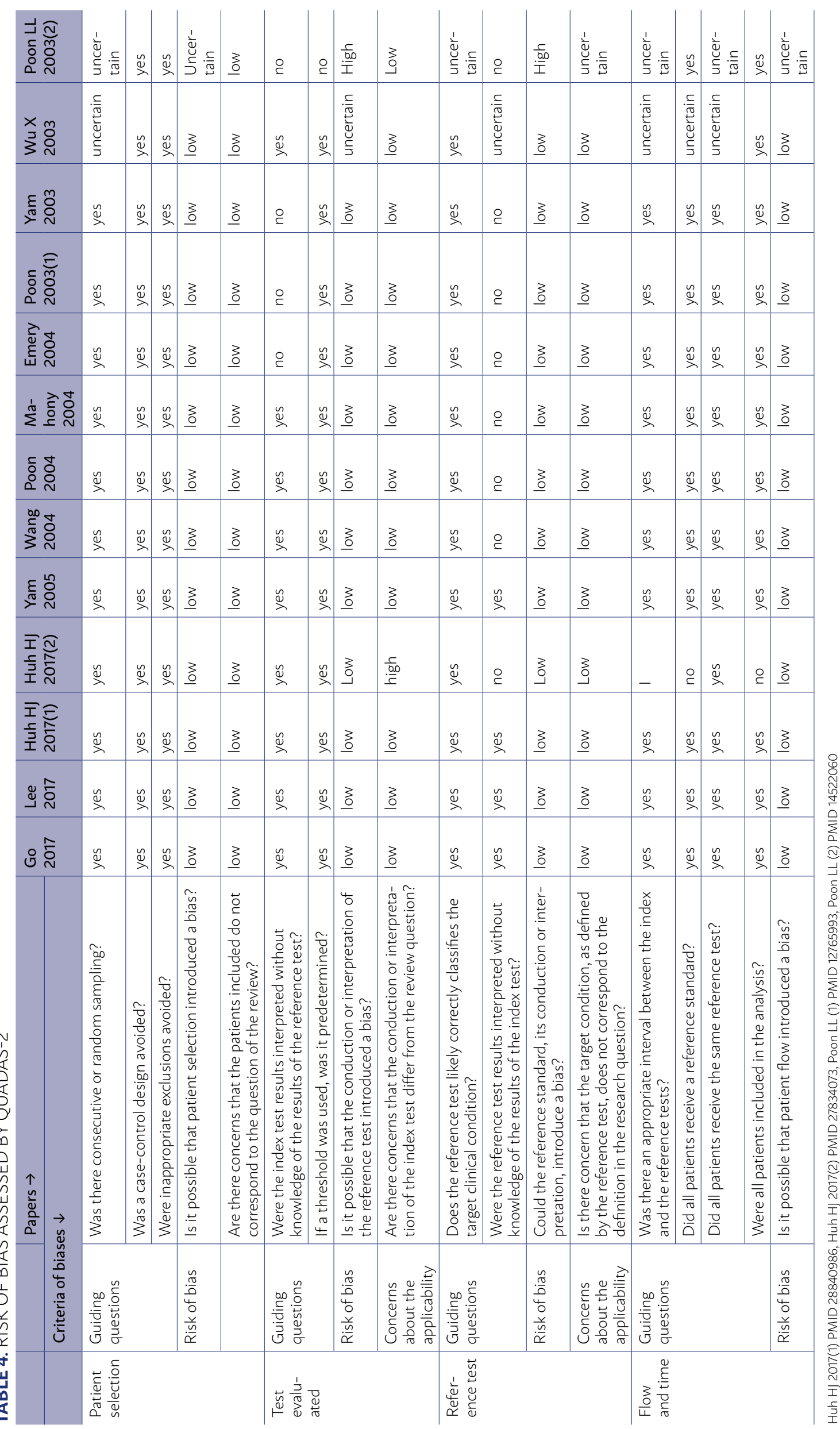




\section{REFERENCES}

1. Wu F, Zhao S, Yu B, et al. A new coronavirus associated with human respiratory disease in China [published correction appears in Nature. 2020 Apr;580(7803):E7]. Nature. 2020;579(7798):265-269. doi:10.1038/ s41586-020-2008-3.

2. Guan WJ, Ni ZY, Hu Y, et al. Clinical Characteristics of Coronavirus Disease 2019 in China. N Engl | Med. 2020;382(18):1708-1720. doi:10.1056/ NEJMoa2002032

3. COVID-19(Dashboard), World Health Organization, Disponível em: <https://covid19.who.int/>. Acessado em 14 de junho de 2020.

4. Sorensen MD, Sørensen B, Gonzalez-Dosal R, et al. Severe acute respiratory syndrome (SARS): development of diagnostics and antivirals. Ann N Y Acad Sci. 2006;1067(1):500-505. doi:10.1196/annals.1354.072

5. Loeffelholz MJ, Tang YW. Laboratory diagnosis of emerging human coronavirus infections - the state of the art. Emerg Microbes Infect. 2020;9(1):747756. doi:10.1080/22221751.2020.1745095

6. Huh HJ, Ko JH, Kim YE, et al. Importance of Specimen Type and Quality in Diagnosing Middle East Respiratory Syndrome. Ann Lab Med. 2017;37(1):8183. doi:10.3343/alm.2017.37.1.81

7. Gezer NS, Ergan B, Barış MM, et al. COVID-19 S: A new proposal for diagnosis and structured reporting of COVID-19 on computed tomography imaging [published online ahead of print, 2020 Jun 19]. Diagn Interv Radiol. 2020;10.5152/dir.2020.20351. doi:10.5152/dir.2020.20351

8. Huh HJ, Ko JH, Kim YE, et al. Importance of Specimen Type and Quality in Diagnosing Middle East Respiratory Syndrome. Ann Lab Med. 2017;37(1):8183. doi:10.3343/alm.2017.37.1.81

9. Hong KH, Lee SW, Kim TS, et al. Guidelines for Laboratory Diagnosis of Coronavirus Disease 2019 (COVID-19) in Korea. Ann Lab Med. 2020;40(5):351-360. doi:10.3343/alm.2020.40.5.351

10. Padoan A, Cosma C, Sciacovelli L, Faggian D, Plebani M. Analytical performances of a chemiluminescence immunoassay for SARS-CoV-2 lgM/lgG and antibody kinetics [published online ahead of print, $2020 \mathrm{Apr} 16$ ]. Clin Chem Lab Med. 2020;/j/cclm.ahead-of-print/cclm-2020-0443/cclm-20200443.xml. doi:10.1515/cclm-2020-0443

11. Lippi G, Simundic AM, Plebani M. Potential preanalytical and analytical vulnerabilities in the laboratory diagnosis of coronavirus disease 2019 (COVID-19) [published online ahead of print, 2020 Mar 16]. Clin Chem Lab Med. 2020;/j/cclm.ahead-of-print/cclm-2020-0285/cclm-2020-0285. xml. doi:10.1515/cclm-2020-0285

12. Corman VM, Eckerle I, Bleicker T, et al. Detection of a novel human coronavirus by real-time reverse-transcription polymerase chain reaction [published correction appears in Euro Surveill. 2012;17(40): pii/20288]. Euro Surveill. 2012;17(39):20285. Published 2012 Sep 27. doi:10.2807/ese.17.39.20285-en

13. Corman VM, Müller MA, Costabel U, et al. Assays for laboratory confirmation of novel human coronavirus ( $\mathrm{hCoV}$-EMC) infections. Euro Surveill. 2012;17(49):20334. Published 2012 Dec 6. doi:10.2807/ese.17.49.20334-en

14. Whiting PF, Rutjes AW, Westwood ME, et al. QUADAS-2: a revised too for the quality assessment of diagnostic accuracy studies. Ann Intern Med. 2011;155(8):529-536. doi:10.7326/0003-4819-155-8-201110180-00009

15. https ://doi.org/10.7326/0003-4819-155-8-20111 0180-00009

16. Centre for Evidence-Based Medicine. CATMaker and EBM calculators

17. [Internet]. Oxford: CEBM; c2018 [cited 2018 Dec 7]. Available from: https:// www.cebm.net/2014/06/catmaker-ebm-calculators/.

18. Zamora |, Abraira V, Muriel A, Khan K, Coomarasamy A. Meta-DiSc: a software for meta-analysis of test accuracy data. BMC Med Res Methodol. 2006; 6:31. Published 2006 Jul 12. doi:10.1186/1471-2288-6-31
19. Huh HJ, Kim JY, Kwon HJ, et al. Performance Evaluation of the PowerChek MERS (upE \& ORF1a) Real-Time PCR Kit for the Detection of Middle East Respiratory Syndrome Coronavirus RNA. Ann Lab Med. 2017;37(6):494-498. doi:10.3343/alm.2017.37.6.494

20. Go YY, Kim YS, Cheon S, et al. Evaluation and Clinical Validation of Two Field-Deployable Reverse Transcription-Insulated Isothermal PCR Assays for the Detection of the Middle East Respiratory Syndrome-Coronavirus. J Mol Diagn. 2017;19(6):817-827. doi: 10.1016/j.jmoldx.2017.06.007

21. Lee JS, Ahn JS, Yu BS, et al. Evaluation of a Real-Time Reverse Transcription-PCR (RT-PCR) Assay for Detection of Middle East Respiratory Syndrome Coronavirus (MERS-CoV) in Clinical Samples from an Outbreak in South Korea in 2015. / Clin Microbiol. 2017;55(8):2554-2555. doi:10.1128/ ICM.00667-17

22. Huh HJ, Ko JH, Kim YE, et al. Importance of Specimen Type and Quality in Diagnosing Middle East Respiratory Syndrome. Ann Lab Med. 2017;37(1):8183. doi:10.3343/alm.2017.37.1.81

23. Yam WC, Chan $\mathrm{KH}$, Chow KH, et al. Clinical evaluation of real-time PCR assays for rapid diagnosis of SARS coronavirus during outbreak and post-epidemic periods. J Clin Virol. 2005;33(1):19-24. doi: 10.1016/j.jcv.2004.09.029

24. Wang $H, M a o Y$, Ju L, et al. Detection and monitoring of SARS coronavirus in the plasma and peripheral blood lymphocytes of patients with severe acute respiratory syndrome. Clin Chem. 2004;50(7):1237-1240. doi:10.1373/ clinchem.2004.031237

25. Poon LL, Wong BW, Chan KH, et al. A one step quantitative RT-PCR for detection of SARS coronavirus with an internal control for PCR inhibitors. / Clin Virol. 2004;30(3):214-217. doi:10.1016/j.jcv.2003.12.007

26. Mahony JB, Petrich A, Louie L, et al. Performance and Cost evaluation of one commercial and six in-house conventional and real-time reverse transcription-pcr assays for detection of severe acute respiratory syndrome coronavirus. J Clin Microbiol. 2004;42(4):1471-1476. doi:10.1128/ jcm.42.4.1471-1476.2004

27. Emery SL, Erdman DD, Bowen MD, et al. Real-time reverse transcription-polymerase chain reaction assay for SARS-associated coronavirus. Emerg Infect Dis. 2004;10(2):311-316. doi:10.3201/eid1002.030759

28. Yam WC, Chan KH, Poon LL, et al. Evaluation of reverse transcription-PCR assays for rapid diagnosis of severe acute respiratory syndrome associated with a novel coronavirus. / Clin Microbiol. 2003;41(10):4521-4524. doi:10.1128/ jcm.41.10.4521-4524.2003

29. Poon LL, Chan KH, Wong OK, et al. Early diagnosis of SARS coronavirus infection by real time RT-PCR. J Clin Virol. 2003;28(3):233-238. doi:10.1016/j. jcv.2003.08.004

30. Wu X, Cheng G, Di B, et al. Establishment of a fluorescent polymerase chain reaction method for the detection of the SARS-associated coronavirus and its clinical application. Chin Med J (Engl). 2003;116(7):988-990.

31. Poon LL, Wong OK, Chan KH, et al. Rapid diagnosis of a coronavirus associated with severe acute respiratory syndrome (SARS) [published correction appears in Clin Chem. 2003 Jul;49(7):1234]. Clin Chem. 2003;49(6 Pt 1):953955. doi:10.1373/49.6.953

32. Deeks |I, Dinnes |, Takwoingi $Y$, et al. Antibody tests for identification of current and past infection with SARS-CoV-2. Cochrane Database Syst Rev. 2020;6:CD013652. Published 2020 Jun 25. doi:10.1002/14651858. CD013652

33. Lippi G, Simundic AM, Plebani M. Potential preanalytical and analytical vulnerabilities in the laboratory diagnosis of coronavirus disease 2019 (COVID-19). Il.color. Disponível em: Clin Chem Lab Med. 2020;58(7):10701076. doi:10.1515/cclm-2020-0285 